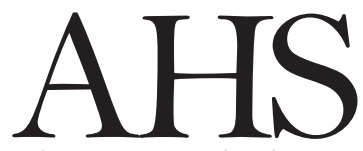

Advances in Horticultural Science

\title{
Exogenous salicylic acid and ferulic acid improve growth, phenolic and carotenoid content in tomato
}

\author{
P.H. Gorni ${ }^{(*)}$, B. da Silva Cornelissen, A.A. Pereira \\ Faculdades Gammon, Engenharia Agronômica, Rua Prefeito Jayme \\ Monteiro, 791, 19700-000 Paraguaçu Paulista, São Paulo, Brazil.
}

Key words: Elicitation, fruit quality, phenolic compounds, secondary metabolites, Solanum lycopersicum.

OPEN ACCESS

$\left.{ }^{*}\right)$ Corresponding author:
pgorni@gmail.com

Citation:

GORNI P.H., DA SILVA CORNELISSEN B., PEREIRA A.A., 2021 - Exogenous salicylic acid and ferulic acid improve growth, phenolic and carotenoid content in tomato. - Adv. Hort. Sci., 35(4): 335341.

\section{Copyright:}

(C) 2021 Gorni P.H., da Silva Cornelissen B., Pereira A.A. This is an open access, peer reviewed article published by Firenze University Press (http://www.fupress.net/index.php/ahs/) and distributed under the terms of the Creative Commons Attribution License, which permits unrestricted use, distribution, and reproduction in any medium, provided the original author and source are credited.

Data Availability Statement:

All relevant data are within the paper and its Supporting Information files.

\section{Competing Interests:}

The authors declare no competing interests.

Received for publication 3 March 2020 Accepted for publication 3 September 2021

\begin{abstract}
Salicylic acid (SA) and ferulic acid (FA) are considered phenolic compounds that act as elicitors due to their regulatory functions on plant growth, development, metabolic and physiological responses in plants. The aim of this research was to evaluate the effect of SA and FA on growth, fruit quality and synthesis of secondary metabolites in tomato (Solanum lycopersicum cultivar Santa Clara). The experiment was conducted in pots in a greenhouse. The application of SA and FA was performed at concentration of $1.0 \mathrm{mmol} \mathrm{L}^{-1}$ alone and in combination, with water treated plants as control. Exogenous application of SA and FA either alone or in combination (SA + FA) resulted in increases in biomass accumulation and chlorophyll contents in tomato plant; and soluble sugar, total polyphenol, flavonoids, lycopene and $\beta$-carotene contents in fruits. It was concluded that application of SA and FA resulted in higher production and concentration of secondary compounds in tomato.
\end{abstract}

\section{Introduction}

Tomato (Solanum lycopersicum L.) belongs to the Solanaceae family and it is considered as low-calorie food. It is a good source of vitamins A, $C$ and $E$, and mineral salts (Adalid et al., 2010; Kazemi, 2014). In addition to vitamins and minerals, tomato has a high lycopene and $\beta$-carotene content, which has antioxidant and anticancer properties. Carotenoids is naturally present in many fruits and vegetables and plays an important role as a functional food when consumed as part of the diet, producing specific health benefits such as reducing the risk of various diseases (Martínez-Hernández et al., 2016; Mehta et al., 2018) and polyphenols (flavonoids, flavanones and flavones) are also present in significant amount in tomato acting as antioxidant, anti-mutagenic, anti-proliferative, anti-inflammatory and anti-atherogenic activities (Martí et al., 2016; Chaudhary et al., 2018).

Salicylic acid (SA), a natural plant hormone, act as an important signalling molecule triggering tolerance against abiotic and biotic stresses 
(Hernández-Ruiz and Arnao, 2018; Gorni et al., 2020; Gorni et al., 2021). SA plays a significant role in many physiological and biochemical processes of the plant, being able to act as growth regulators and also as an abiotic elicitor capable of increasing the synthesis of secondary compounds beneficial to human health (Javanmardi and Akbari, 2016).

Ferulic acid (FA) is a phenolic compound synthetized from the metabolism of phenylalanine and tyrosine in plants. It is an important biological and structural component of the plant cell wall and it accumulates in soil and influences plant growth (Li et al., 2013; Paiva et al., 2013). FA is considered as nonenzymatic antioxidant and acts under stress to eliminate free radicals produced in plants (Andreasen et al., 2001; Engwa, 2018). Studies on the exogenous application of FA in plants have demonstrated that this compound acts as an important regulator of several physiological processes related to plant growth and mitigating stress, such as, stomatal closure, cell division, membrane permeability, photosynthesis, respiration and many other metabolic processes (Santos et al., 2008; Li et al., 2013; Singh and Deen, 2014; Hussain et al., 2017; Cheng et al., 2018).

However, exogenous SA (Kazemi, 2014) and FA (Singh and Deen, 2014) applications were effective in inducing the growth and formation of secondary metabolites in tomato plants. Therefore, it is suggested that the application of SA and FA may result in combined effects of growth promotion and induction of biosynthetic pathways of secondary metabolism. Previous studies have revealed the hormonal and eliciting action of SA and FA $\left(1.0 \mathrm{mmol} \mathrm{L}^{-1}\right)$ in tomato plants (Hussain et al., 2017; Kumar et al., 2017). In this context, the application of SA and FA can improve the productive performance and the biosynthesis of secondary compounds in tomato, making possible an increase in the commercial value of this crop, reaching greater market competitiveness. In this study we evaluated the effect of leaf spray of SA and FA either alone and in combination on the growth, yield and secondary compounds in tomato cultivar Santa Clara.

\section{Materials and Methods}

The experiment was conducted under greenhouse (without temperature and humidity control) covered with a $50 \%$ solar radiation shade located in Gammon

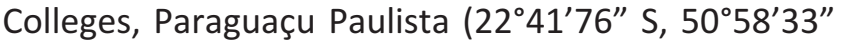
W, 517 a.s.I.), Sao Paulo, Brazil.

Trademark tomato cultivar Santa Clara seeds were placed in a germination tray and after the training period ( 30 days) they were planted in $18 \mathrm{~L}$ pots containing soil. Soil samples were collected and submitted to chemical analysis according to Van Raij et al. (2001) (Table 1) and was corrected by applying limestone to increase the saturation of bases to $80 \%$ $\left(40.0 \mathrm{~g} \mathrm{pots}^{-1}\right)$, potassium chloride $\left(3.0 \mathrm{~g} \mathrm{pots}^{-1}\right)$ and simple super phosphate $\left(20.0 \mathrm{~g} \mathrm{pots}^{-1}\right)$. For fertilization with micronutrients it was added Yoorin Master $1 \mathrm{Si}^{\circ}$ (granulated) (Si: 10\%, B: 0.1\%, Mn: 0.3\%, Cu: $0.05 \%$ and $\mathrm{Zn}: 0.55 \%)\left(1.5 \mathrm{~g}_{\text {pots }}{ }^{-1}\right)$, according to the recommendations of Bulletin 100 (IAC) for tomato species. The pots were irrigated by sprinklers per day at 8 a.m. and 5 p.m. in order to keep the soil moisture and ensure the availability of water throughout the experimental period.

The application of salicylic acid (SA: $138.121 \mathrm{~g} \mathrm{~mol}^{-}$ $\left.{ }^{1}\right)$ and ferulic acid (FA: $194.18 \mathrm{~g} \mathrm{~mol}^{-1}$ ) was made for 3 consecutive days after having reached 20 days from transplant. Foliar applications of SA and FA at a dose of $1.0 \mathrm{mmol} \mathrm{L}^{-1}$ alone and in combination, and watertreated plants were used as control. SA and FA treatments were carried out by spraying the shoots of the plants with water-based solutions supplemented with $\mathrm{Agral}^{\circledR}\left(50 \mu \mathrm{L} \mathrm{L}^{-1}\right.$ of solution) until the drop point (10 mL per plant), as follows: T1 - plants sprayed only with water (Control); T2 - applications of $1.0 \mathrm{mmol} \mathrm{L}^{-1}$ SA (SA); T3 - applications of $1.0 \mathrm{mmol} \mathrm{L}^{-1} \mathrm{FA}(\mathrm{FA})$; and $\mathrm{T} 4$ - applications of $1.0 \mathrm{mmol} \mathrm{L}^{-1} \mathrm{SA}+1.0 \mathrm{mmol} \mathrm{L}^{-1} \mathrm{FA}$ (SA + FA) by spraying the plants for three consecutive days.

Plants were harvested 90 days after transplanting the seedlings by collecting leaves, roots and fruits.

\section{Plant growth}

The effect of SA and FA on the plants were evalu-

Table 1 - Chemical analysis of the soil used in the experiment

\begin{tabular}{|c|c|c|c|c|c|c|}
\hline $\mathrm{pH}$ & $\begin{array}{l}\text { Organic matter } \\
\qquad \mathrm{g} \mathrm{dm}^{-3}\end{array}$ & $\begin{array}{c}\mathrm{H}+\mathrm{Al} \\
\mathrm{mmolc} \mathrm{dm}{ }^{-3}\end{array}$ & $\begin{array}{c}\mathrm{Ca} \\
\text { mmolc } \mathrm{dm}^{-3}\end{array}$ & $\begin{array}{c}\mathrm{Mg} \\
\mathrm{mmolc} \mathrm{dm}^{-3}\end{array}$ & $\begin{array}{c}\mathrm{K} \\
\mathrm{mmolc} \mathrm{dm}^{-3}\end{array}$ & $\begin{array}{c}P \\
m g d m^{-3}\end{array}$ \\
\hline 4.4 & 6.0 & 20.0 & 7.0 & 2.0 & 0.8 & 6.0 \\
\hline
\end{tabular}


ated based on the fallowing: leaf area $\left(\mathrm{cm}^{2}\right)$, number of leaves per plant, number of fruits per plant, plant height $(\mathrm{cm})$, dry weight of shoot and roots $\left(\mathrm{g} \mathrm{plant}^{-1}\right)$ and mean fruit weight $\left(\mathrm{g} \mathrm{plant}^{-1}\right)$. The leaf area was assessed using Image ${ }^{\circ}$ Software (Powerful Image Analysis) with 5 plants per treatment. The number of leaves and fruit per plant was determined by manual counting, considering fully expanded leaves and fruits at harvest point. The plant height was determined by measuring tape. The shoot and root dry weight were determined after drying in an oven with air circulation at $70^{\circ} \mathrm{C}$ until constant weight.

\section{Chlorophyll content}

Chlorophyll content ( $\mu \mathrm{g} \mathrm{mL}^{-1}$ ) was determined spectrophotometrically following extraction in acetone, according to the method of Lichtenthaler (1987). Fresh leaf tissue $(0.6 \mathrm{~g})$ was added in $7 \mathrm{~mL}$ of $80 \%$ acetone, the tubes were shaken and left to stand for 30 minutes. The readings were performed in a spectrophotometer at $\lambda 663$ and $\lambda 645 \mathrm{~nm}$.

\section{Total soluble sugar content}

Total soluble sugar content in fruit was determined according to the method described by Dubois et al. (1956) using glucose as the standard. Fresh tissue $(0.1 \mathrm{~g})$ was added in $10 \mathrm{~mL}$ of $80 \%$ ethanol, and macerated in a mortar and left to rest for $30 \mathrm{~min}$. The analyzes followed with the addition of phenol (5\%) and sulfuric acid ( $98 \mathrm{~N}$ ). The readings were performed in a spectrophotometer at $\lambda 490 \mathrm{~nm}$.

\section{Preparation of fruit tomato extract}

Determinations of total polyphenolic compounds and total flavonoid were obtained from the tomato juice. The fruits were ground in a low speed food processor (3000 rpm) for two minutes and passed in 2 $\mathrm{mm}$ sieves.

\section{Total polyphenols contents}

Total polyphenols contents were determined spectrophotometrically ( $\lambda 765 \mathrm{~nm}$ ) by Folin-Ciocalteu method with modification described by Stagos et al. (2012). The total polyphenols contents were reported based on micrograms of gallic acid equivalents per

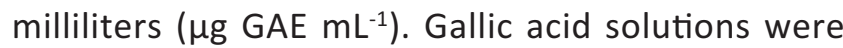
prepared with concentrations of 25 to $500 \mu \mathrm{g} \mathrm{mL}^{-1}$ in absolute ethyl alcohol. The assays were performed in triplicate.

\section{Total flavonoid content}

Total flavonoid content was determined spectrophotometrically $(\lambda 510 \mathrm{~nm})$ by the method of Yao et al. (2013). The total flavonoids contents were reported based on micrograms of rutin equivalents per milliliters ( $\mu \mathrm{g} \mathrm{RE} \mathrm{mL}^{-1}$ ). Rutin solutions were prepared with concentrations of 25 to $500 \mu \mathrm{g} \mathrm{mL}^{-1}$ in absolute ethyl alcohol. The assays were performed in triplicate.

\section{Carotenoid content}

Carotenoid content were extracted from fresh tomato samples after homogenisation of whole fruits. The homogenised sample was mixtured with chloroform/acetone/ethanol (2:1:1, v/v/v) (Sadler et al., 1990). For the determination of lycopene and $\beta$ carotene, the absorbance was read at $\lambda 470$ and $\lambda$ $450 \mathrm{~nm}$. Carotenoid content were determined according to the equation described by Craft and Soares (1992), using the molar extinction coefficient of 3450 for lycopene, and 2592 for $\beta$-carotene and expressed in micrograms per grams $\left(\mu \mathrm{g} \mathrm{g}^{-1}\right)$. The assays were performed in triplicate.

\section{Statistical analysis}

The experiment was arranged in a completely randomized design with four treatments and five replications per treatment. The Shapiro-Wilk test was used to ensure the normality assumption and the homogeneity of variances. The data were submitted to analysis of variance $(p \leq 0.05)$ and Tukey test $(p \leq 0.01)$ using the SISVAR software. The results were presented by means of the treatments and standard error.

\section{Results}

The results indicated that SA and FA both caused a significant increase of growth in tomato (Table 2). The exogenous application of $1.0 \mathrm{mmol} \mathrm{L}^{-1} \mathrm{SA}$ resulted in increasing in the accumulation of root dry weight by $61 \%$ and total dry weight by $41.3 \%$ compared to control plants. The application of $1.0 \mathrm{mmol} \mathrm{L}^{-1}$ FA resulted in increasing in shoot dry mass by $52.3 \%$ and total dry mass by $52 \%$ compared to control plants. However, the interaction between SA + FA resulted in increasing in shoot dry mass by $51.5 \%$, root dry mass by $146.37 \%$ and total dry mass by $66.6 \%$, when compared to control plants. Fruit weight increased by $16.5 \%$ in plant treated with 1.0 $\mathrm{mmol} \mathrm{L} \mathrm{L}^{-1} \mathrm{FA}$.

The exogenous application of SA + FA resulted in increasing the leaf area by $47 \%$ and number of leaves by $204.3 \%$ compared to control plants (Table 3 ). Application of SA and FA showed increasing of 101.8 
Adv. Hort. Sci., 2021 35(4): 335-341

Table 2 - Effect of salicylic acid and ferulic acid on the shoot, root, total dry weight and fruit weight in tomato

\begin{tabular}{lcccc}
\hline Treatments & $\begin{array}{c}\text { Shoot dry weight } \\
\left(\mathrm{g} \mathrm{plant}^{-1}\right)\end{array}$ & $\begin{array}{c}\text { Root dry weight } \\
\left(\mathrm{g} \mathrm{plant}^{-1}\right)\end{array}$ & $\begin{array}{c}\text { Total dry weight } \\
\left.\text { (g plant }^{-1}\right)\end{array}$ & $\begin{array}{c}\text { Fruit weight } \\
\left(\mathrm{g} \mathrm{plant}^{-1}\right)\end{array}$ \\
\hline Control & $24.01 \pm 1.11 \mathrm{c}$ & $4.55 \pm 0.83 \mathrm{c}$ & $28.57 \pm 1.60 \mathrm{c}$ & $524.46 \pm 2.07 \mathrm{~b}$ \\
SA & $33.06 \pm 1.59 \mathrm{abc}$ & $7.32 \pm 0.36 \mathrm{~b}$ & $40.38 \pm 1.60 \mathrm{~b}$ & $554.29 \pm 7.44 \mathrm{~b}$ \\
FA & $36.57 \pm 2.35 \mathrm{a}^{* *}$ & $6.84 \pm 0.42 \mathrm{bc}$ & $43.41 \pm 1.86 \mathrm{ab}$ & $610.78 \pm 11.94 \mathrm{a} * *$ \\
SA + FA & $36.38 \pm 3.99 \mathrm{a}$ & $14.02 \pm 1.72 \mathrm{a} * *$ & $47.59 \pm 4.57 \mathrm{a}^{* *}$ & $525.40 \pm 20.23 \mathrm{~b}$ \\
CV (\%) & 15.78 & 15.08 & 12.04 & 5.39 \\
\hline
\end{tabular}

Different letters indicate significant differences by Tukey's test $(p \leq 0.01)$.

Table 3 - Effect of salicylic acid and ferulic acid on leaf area, number of leaves per plant, number of fruits per plant and plant height in tomato

\begin{tabular}{lcccc}
\hline Treatments & Leaf area $\left(\mathrm{cm}^{2}\right)$ & Number of leaves & Number of fruits & Plant height (cm) \\
& & & & \\
\hline Control & $7955.4 \pm 466.9 \mathrm{~b}$ & $65.2 \pm 3.69 \mathrm{c}$ & $20.8 \pm 0.86 \mathrm{~b}$ & $77.4 \pm 2.67 \mathrm{~ns}$ \\
SA & $8739.6 \pm 1054.1 \mathrm{ab}$ & $131.6 \pm 16.02 \mathrm{~b}$ & $35.4 \pm 3.81 \mathrm{a} * *$ & $79.6 \pm 2.75$ \\
FA & $10209.8 \pm 850.6 \mathrm{ab}$ & $174.4 \pm 10.49 \mathrm{ab}$ & $35.0 \pm 3.20 \mathrm{a}$ & $88.2 \pm 7.20$ \\
SA + FA & $11691.6 \pm 577.1 \mathrm{a} *$ & $198.4 \pm 10.09 \mathrm{a} * *$ & $28.6 \pm 0.40 \mathrm{ab}$ & $77.0 \pm 1.04$ \\
CV (\%) & 16.11 & 16.71 & 19.89 & 10.75 \\
\hline
\end{tabular}

Different letters indicate significant differences by Tukey's test $(p \leq 0.01)$.

and $167.5 \%$ for the number of leaves, 70.2 and $68.3 \%$ for the number of fruits, when compared with control plants (Table 3 ). The plant height treated with SA and FA was not changed in relation to control plants.

Chlorophyll a content (Table 4) observed in tomato plants treated with $S A, F A$ and the interaction with SA + FA were significantly higher by 26,12 and $27.6 \%$, respectively compared to control. Chlorophyll $b$ and total chlorophyll decreased with the application the elicitors (Table 4). The total soluble sugar content in fruits, increased up to $36 \%$ in $1.0 \mathrm{mmol} \mathrm{L}^{-1}$ $\mathrm{SA}$ and $163 \%$ in $1.0 \mathrm{mmol} \mathrm{L}^{-1} \mathrm{FA}$ treated plants when compared to the control.
The exogenous application of SA, FA and the interaction with SA + FA resulted in increasing in the accumulation of total polyphenols of $20.4,110.3$ and $12 \%$, in relation to control plants (Table 5). Total flavonoid content in tomato were 81,107 and $37 \%$ higher in SA, FA and the combined with SA + FA treatments when compared to control plants, respectively. In relation to carotenoid content plants treated with SA also presented increases of $157.3 \%$ (lycopene), and $157.7 \%$ ( $\beta$-carotene). The combination of SA+FA showed increases of $65.25 \%$ (lycopene), and $65.3 \%$ ( $\beta$-carotene), respectively, in comparison to the control (Table 5).

Table 4 - Effect of salicylic acid and ferulic acid on the chlorophyll and fruit total soluble sugar contents in tomato

\begin{tabular}{|c|c|c|c|c|}
\hline Treatments & $\begin{array}{l}\text { Chlorophyll } a \\
\quad\left(\mu \mathrm{g} \mathrm{mL} L^{-1}\right)\end{array}$ & $\begin{array}{l}\text { Chlorophyll } b \\
\quad\left(\mu \mathrm{gL}^{-1}\right)\end{array}$ & $\begin{array}{l}\text { Total chlorophyll } \\
\qquad\left(\mu \mathrm{g} \mathrm{mL}^{-1}\right)\end{array}$ & $\begin{array}{l}\text { Fruit total soluble sugar } \\
\qquad\left(\mathrm{mg} \mathrm{g}^{-1}\right)\end{array}$ \\
\hline Control & $9.66 \pm 0.23 c$ & $21.02 \pm 0.13 a^{* *}$ & $30.68 \pm 0.14 a^{* *}$ & $22.63 \pm 0.96 \mathrm{c}$ \\
\hline SA & $12.13 \pm 0.07 \mathrm{a}$ & $15.69 \pm 0.02 c$ & $27.88 \pm 0.04 c$ & $30.77 \pm 1.38 b$ \\
\hline FA & $10.82 \pm 0.04 b$ & $13.03 \pm 0.08 \mathrm{~d}$ & $23.90 \pm 0.05 \mathrm{~d}$ & $59.47 \pm 1.92 \mathrm{a} * *$ \\
\hline$S A+F A$ & $12.33 \pm 0.07 \mathrm{a} * *$ & $16.05 \pm 0.02 b$ & $28.45 \pm 0.04 b$ & $26.89 \pm 0.21 b c$ \\
\hline CV (\%) & 1.73 & 0.73 & 0.59 & 7.30 \\
\hline
\end{tabular}

Different letters indicate significant differences by Tukey's test $(p \leq 0.01)$. 
Table 5 - Pair-wise genetic distance estimates based on observed phenotypes of 21 Amaranthus accessions

\begin{tabular}{lcccc}
\hline Treatments & $\begin{array}{c}\text { Polyphenols } \\
\left.(\mu \mathrm{g} \mathrm{GAE} \mathrm{mL})^{-1}\right)\end{array}$ & $\begin{array}{c}\text { Flavonoid } \\
\left.(\mu \mathrm{gRE} \mathrm{mL})^{-1}\right)\end{array}$ & $\begin{array}{c}\text { Lycopene } \\
\left(\mu \mathrm{g} \mathrm{g}^{-1}\right)\end{array}$ & $\begin{array}{c}\beta \text {-carotene } \\
\left(\mu \mathrm{g} \mathrm{g}^{-1}\right)\end{array}$ \\
\hline Control & $245.58 \pm 7.21 \mathrm{c}$ & $272.33 \pm 4.81 \mathrm{~d}$ & $7.54 \pm 0.16 \mathrm{c}$ & $10.03 \pm 0.2 \mathrm{c}$ \\
SA & $295.58 \pm 12.02 \mathrm{~b}$ & $493.16 \pm 2.40 \mathrm{~b}$ & $19.4 \pm 0.16 \mathrm{a} * *$ & $25.85 \pm 0.2 \mathrm{a} * *$ \\
FA & $516.42 \pm 0.00 \mathrm{a} * *$ & $564.00 \pm 4.81 \mathrm{a} * *$ & $6.96 \pm 0.16 \mathrm{c}$ & $9.25 \pm 0.2 \mathrm{c}$ \\
SA + FA & $274.75 \pm 4.81 \mathrm{~b}$ & $372.33 \pm 4.81 \mathrm{c}$ & $12.46 \pm 0.00 \mathrm{~b}$ & $16.58 \pm 0.0 \mathrm{~b}$ \\
CV (\%) & 2.60 & 1.85 & 2.39 & 2.17 \\
\hline
\end{tabular}

Different letters indicate significant differences by Tukey's test $(p \leq 0.01)$.

\section{Discussion and Conclusions}

Tomato plants treated with SA and FA presented higher total biomass (Table 2). The effect of elicitors plays a key role in growth regulation, plant development and these findings can be associated with the changes in hormone functions or the improvement of photosynthesis and carbohydrate accumulation in plants (Hussain et al., 2017; Gorni et al., 2020). The foliar application of SA and FA trigger a greater cellular activity that result in a larger number of leaves and leaf area, thus presenting a larger photosynthetic surface, improving the physiological processes (Gorni and Pahceco, 2016; Hussain et al., 2017). Regarding the increase of leaf area, number of leaves, number of fruits and fruit weight, our results showed that the application of SA and FA can alter the growing pattern, in tomato plants (Table 3). The application of SA and FA increased the growth of leaves and roots, without changing the plant height (Khan et al., 2003; de Carvalho et al., 2020). Biomass gains as an effect of SA application were also observed in Achillea millefolium (Gorni and Pacheco, 2016), Foeniculum vulgare (Gorni et al., 2017) and Mentha spicata (Kundu et al., 2018). Increase in biomass, were also observed after FA application in plants of Arabidopsis thaliana (Reigosa and Pazos-Malvido, 2007), Pisum sativum (Orcaray et al., 2011) and Cucumis sativus (Li et al., 2013).

Pigments are the essential components for growth and development and they can determine the health status of plants (Hussain et al., 2017; Gorni et al., 2020). Based on our results, the application the elicitors SA and FA alone or in combination suggest an increase in chlorophyll $a$ (Table 4). On the other hand, the application of SA and FA did not affect the chlorophyll $b$ and total chlorophyll content, which directly reflected in the plant height values
(Table 3). Anway, other studies conducted on different species reported increases in chlorophyll $a$, chlorophyll $b$ and total chlorophyll contents consequences of SA treatment (Kazemi, 2014; Chakraborty et al., 2016) and in plants sprayed with FA (Zhu and Wakisaka, 2018). Positive effects of SA and FA on the physiological processes of tomato suggest that these elicitors may be associated with the regulation of several essential primary metabolic processes, including synthesis of chlorophylls (Zhu and Wakisaka, 2018; Gorni et al., 2020).

The positive effects of the application of SA and FA on the physiological processes of tomato plants were also reflected in higher soluble sugar content (Table 4). Sugar is one of the ingredients in tomato (Hafeznia et al., 2014), and it is an important organic solute with low molecular weight in higher plants. The sugars which are accumulated under stress conditions or as consequence of treatments with SA or FA, keeping osmotic regulation and turgor inside the plant (Orcaray et al., 2011; Gorni et al., 2020). Results show that application of SA also resulted in increasing the total soluble sugar content in tomato plants (Kazemi, 2014), and chamomile (Zarinkamar et al., 2013); similarly to application of FA in pea (Orcaray et al., 2011) and soybean (Ferrarese et al., 2001).

Polyphenols and flavonoids provide many physiological functions for plant survival and are of fundamental importance for plants adaptation (Verma and Shukla, 2015; Mehta et al., 2018). Our results suggest that the application of SA and FA may modulate and alter the concentration of polyphenolic compounds (Table 5) in tomato plants. Studies report that the application of SA and FA stimulates the phenylpropanoid pathway, increasing the accumulation of polyphenols and flavonoids in plants (Salvador et al., 2013; Gorni et al., 2021).

Tomato plants have a good free radical scavenging capacity due to the high concentration of lyco- 
pene and $\beta$-carotene. This pigment, it is the most effective antioxidant which gives color to tomato fruit as maturity progresses (Kumar et al., 2017). Polyphenolic compounds and carotenoid act as antioxidants because they remove singlet oxygen and other free radicals in cells (Shahidi and Ambigaipalan, 2015) due to their ability to donate hydrogen from hydroxyl groups positioned along the aromatic ring to prevent oxidation by radicals free from lipids and other biomolecules (Sousa et al., 2007).

Researchers showed an increase in carotenoid content during ripening due to the gradual degradation of chlorophyll (Adalid et al., 2010). Our results showed that the application of SA and FA may modulate and alter the concentration of lycopene and $\beta$ carotene (Table 5) and chlorophyll $a$ contents (Table 4 ) in tomato plants. Thus, our study evidenced that foliar application of SA and FA in tomato crop could enhance its antioxidant activity due to the higher concentration of these bioactive compounds. Our results corroborate with those found by Kumar et al. (2017), who also reported that foliar application of SA significantly increased lycopene content of tomato fruits. Singh et al. (2010) reported that application of L-phenylalanine and FA increased total polyphenols in pea plants.

Therefore, it can be concluded that application of bioregulators results in higher yield and higher concentration of secondary compounds of Solanum lycopersicum.

\section{References}

ADALID A.M., ROSELLÓ S., NUEZ F., 2010 - Evaluation and selection of tomato accessions (Solanum section Lycopersicon) for content of lycopene, b-carotene and ascorbic acid. - J. Food Compost Anal., 23(6): 613-618.

ANDREASEN M.F., LANDBO A.K., CHRISTENSEN L.P., HANSEN Å., MEYER A.S., 2001 - Antioxidant effects of phenolic rye (Secale cereale L.) extracts, monomeric hydroxycinnamates, and ferulic acid dehydrodimers on human low-density lipoproteins. - J. Agr. Food Chem., 49(8): 4090-4096.

CHAKRABORTY N., GHOSH S., CHANDRA S., SENGUPTA S., ACHARYA K., 2016 - Abiotic elicitors mediated elicitation of innate immunity in tomato: an ex vivo comparison. - Physiol. Mol. Biol. Plants, 22(3): 307-320.

CHAUDHARY P., SHARMA A., SINGH B., NAGPAL A.K., 2018 - Bioactivities of phytochemicals present in tomato. - J. Food Sci. Tech., 55(8): 2833-2849.

CHENG Z.Y., SUN L., WANG X.J., SUN R., AN Y.Q., AN B.L.,
ZHU M.X., ZHAO C.F., BAI J.G., 2018 - Ferulic acid pretreatment alleviates heat stress in blueberry seedlings by inducing antioxidant enzymes, proline, and soluble sugars. - Biol. Plant., 62(3): 534-542.

CRAFT N.E., SOARES Jr. J.H., 1992 - Relative solubility, stability and absorptivity of lutein and beta-carotene in organic solvents. - J. Agr. Food Chem., 40(3): 431-434.

DE CARVALHO J.S.B., DA SILVA J.P.R., BATISTA R.D.C.M., 2020 - Use of salicylic acid as an attenuator to the effects of water deficit on basil plants. - Diversitas J., 5(3): 1561-1574.

DUBOIS M., GILLES K.A., HAMILTON J.K., REBERS P.T., SMITH F., 1956 - Colorimetric method for determination of sugars and related substances. - Anal. Chem., 28(3): 350-356.

ENGWA G.A., 2018 - Free radicals and the role of plant phytochemicals as antioxidants against oxidative stress-related diseases. Phytochemicals: Source of antioxidants and role in disease prevention. - BoD-Books on Demand, 7: 49-74.

FERRARESE M.L.L., SOUZA N.E., RODRIGUES J.D., FERRARESE-FILHO O., 2001 - Carbohydrate and lipid status in soybean roots influenced by ferulic acid uptake. - Acta Physiol. Plant., 23: 421-427.

GORNI P.H., BROZULATO M.O., LOURENÇÃO R.S., KONRAD E.C.G., 2017 - Increased biomass and salicylic acid elicitor activity in fennel (Foeniculum vulgare Miller). Braz. J. Food Technol., 20: e2016172.

GORNI P.H., PACHECO A.C., 2016 - Growth promotion and elicitor activity of salicylic acid in Achillea millefolium $L$. - Afr. J. Biotechnol., 15(16): 657-665.

GORNI P.H., PACHECO A.C., LIMA MORO A., SILVA J.F.A., MORELI R.R., DE MIRANDA G.R., PELEGRINI J.M., SPERA K.D., BRONZEL JR J.L., SILVA R.M.G., 2020 - Salicylic acid foliar application increases biomass, nutrient assimilation, primary metabolites and essential oil content in Achillea millefolium L. - Sci. Hort., 270:109436.

GORNI P.H., PACHECO A.C., LIMA MORO A., SILVA J.F.A., MORELI R.R., DE MIRANDA G.R., PELEGRINI J.M., ZANIBONI C.B., SPERA K.D., BRONZEL JR J.L., SILVA R.M.G., 2021 - Elicitation improves the leaf area, enzymatic activities, antioxidant activity and content of secondary metabolites in Achillea millefolium L. grown in the field. - J. Plant Growth, 40(4): 1652-1666.

HAFEZNIA M., MASHAYEKHI K., GHADERIFAR F., MOUSAVIZADEH S.J., 2014 - Tomato morphological and biochemical characteristics in response to foliar applying of salicylic acid. - Int. J. Biosci., 5(9): 237-243.

HERNÁNDEZ-RUIZ J., ARNAO M., 2018 - Relationship of melatonin and salicylic acid in biotic/abiotic plant stress responses. - Agronomy, 8(4): 33.

HUSSAIN I., SINGH N.B., SINGH A., SINGH H., SINGH S.C., YADAV V., 2017 - Exogenous application of phytosynthesized nanoceria to alleviate ferulic acid stress in Solanum lycopersicum. - Sci. Hortic., 214: 158-164.

JAVANMARDI J., AKBARI N., 2016 - Salicylic acid at differ- 
ent plant growth stages affects secondary metabolites and phisico-chemical parameters of greenhouse tomato. - Adv. Hort. Sci., 30(3): 151-157.

KAZEMI M., 2014 - Effect of foliar application with salicylic acid and methyl jasmonate on growth, flowering, yield and fruit quality of tomato. - Bull. Env. Pharmacol. Life Sci., 3(2): 154-158.

KHAN W., PRITHIVIRAJ B., SMITH D.L., 2003 Photosynthetic responses of corn and soybean to foliar application of salicylates.- J. Plant Physiol., 160(5): 485492.

KUMAR S., YADAV A., YADAV M., YADAV J.P., 2017 - Effect of climate change on phytochemical diversity, total phenolic content and in vitro antioxidant activity of Aloe vera (L.) Burm. f. - BMC Res. Notes, 10(1): 60.

KUNDU M., HALDER S., BHATTACHARJEE A., 2018 - Salicylic acid induced modulation of growth and metabolism of a medicinal plant Mentha spicata L. - Int. J. Pharm. Sci. Res., 9(12): 5294-5300.

LI D.M., NIE Y.X., ZHANG J., YIN J.S., LI Q., WANG X.J., BAI J.G., 2013 - Ferulic acid pretreatment enhances dehydration-stress tolerance of cucumber seedlings. - Biol. Plant., 57(4): 711-717.

LICHTENTHALER H.K., 1987 - Chlorophyll and carotenoids: pigments of photosynthetic biomembranes, pp. 350382. - In PACKER L., and R. DOUCE (eds.) Methods enzymology. Academic Press, Sandiego, CA, USA, pp. 762.

MARTI R., ROSELLO S., CEBOLLA-CORNEJO J., 2016 Tomato as a source of carotenoids and polyphenols targeted to cancer prevention. - Cancers, 8(6): 58.

MARTÍNEZ-HERNANDEZ G.B., BOLUDA-AGUILAR M., TABOADA-RODRIGUEZ A., SOTO-JOVER S., MARININIESTA F., LOPEZ-GOMEZ A., 2016 - Processing, packaging, and storage of tomato products: influence on the lycopene content. - Food Eng. Rev., 8(1): 52-75.

MEHTA N., PATANI P., SINGHVI I., 2018 - A review on tomato lycopene. - Int. J. Pharm. Sci. Res., 9(3): 916923.

ORCARAY L., IGAL M., ZABALZA A., ROYUELA M., 2011 Role of exogenously supplied ferulic and p-coumaric acids in mimicking the mode of action of acetolactate synthase inhibiting herbicides. - J. Agr. Food Chem., 59(18): 10162-10168.

PAIVA L.B.D., GOLDBECK R., SANTOS W.D.D., SQUINA F.M., 2013 - Ferulic acid and derivatives: molecules with potential application in the pharmaceutical field. - Braz. J. Pharm. Sci., 49(3): 395-411.

REIGOSA M.J., PAZOS-MALVIDO E., 2007 - Phytotoxic Effects of 21 plant secondary metabolites on Arabidopsis thaliana germination and root growth. - J. Chem. Ecol., 33: 1456-1466.

SADLER G., DAVIS J., DEZMAN D., 1990 - Rapid extraction of lycopene and 8 -carotene from reconstituted tomato paste and pink grapefruit homogenates. - J. Food Sci.,
55(5): 1460-1461.

SALVADOR V.H., LIMA R.B., DOS SANTOS W.D., SOARES A.R., BÖHM P.A.F., MARCHIOSI R., FERRARESE M.L.L., FERRARESE-FILHO O., 2013 - Cinnamic acid increases lignin production and inhibits soybean root growth. PLoS One, 8(7), e69105.

SANTOS W.D., FERRARESE M.L.L., NAKAMURA C.V., MOURÃO K.S.M., MANGOLIN C.A., FERRARESE-FILHO O., 2008 - Soybean (Glycine max) root lignification induced by ferulic acid. The possible mode of action. - J. Chem. Ecology, 34(9): 1230-1241.

SHAHIDI F., AMBIGAIPALAN P., 2015 - Phenolics and polyphenolics in foods, beverages and spices: Antioxidant activity and health effects - $A$ review. - J. Funct. Foods, 18: 820-897.

SINGH D.P., BAHADUR A., SARMA B.K., MAURYA S., SINGH H.B., SINGH U.P., 2010 - Exogenous application of Lphenylalanine and ferulic acid enhance phenylalanine ammonia lyase activity and accumulation of phenolic acids in pea (Pisum sativum) to offer protection against Erysiphe pisi. - Arch. Phytopathol. Plant Protect., 43(15): 1454-1462.

SINGH N.B., DEEN S., 2014 - Allelopathic potential of ferulic acid on tomato. - Tunis. J. Plant Prot., 9(1): 1-9.

SOUSA C.M.M., SILVA H.R., VIEIRA-JUNIOR G.M., AYRES M.C.C., COSTA C.D., ARAÚJO D.S., CAVALCANTE L.C.D., BARROS E.D.S., ARAÚJO P.B.M., BRANDÃO M.S., CHAVES M.H., 2007 - Total phenolics and antioxidant activity of five medicinal plants. - Quím. Nova, 30(2): 351355.

STAGOS D., PORTESIS N., SPANOU C., MOSSIALOS D., ALIGIANNIS N., CHAITA E., PANAGOULIS C., RERI E., SKALTSOUNIS L., TSATSAKI A.M., KOURETAS D., 2012 Correlation of total polyphenolic content with antioxidant and antibacterial activity of 24 extracts from Greek domestic Lamiaceae species. - Food Chem. Toxicol., 50(11): 4115-4124.

VAN RAIJ B., DE ANDRADE J.C., CANTARELLA H., QUAGGIO J.A., 2001 - Chemical analysis for evaluation of fertility of tropical soils. - IAC, Instituto Agronômico de Campinas, Campinas, Brazil.

VERMA N., SHUKLA S., 2015 - Impact of various factors responsible for fluctuation in plant secondary metabolites. - J. Appl. Res. Med. Aromat. Plants, 2(4): 105-113.

YAO X., ZHU L., CHEN Y., TIAN J., WANG Y., 2013 - In vivo and in vitro antioxidant activity and $\alpha$-glucosidase, $\alpha$ amylase inhibitory effects of flavonoids from Cichorium glandulosum seeds. - Food Chem., 139(1-4): 59-66.

ZARINKAMAR F., SADERI Z., SOLEIMANPOUR S., 2013 Excluder strategies in response to $P b$ toxicity in Matricaria chamomilla. - Environ. Ecol. Res., 1(1): 1-11.

ZHU J., WAKISAKA M., 2018 - Growth promotion of Euglena gracilis by ferulic acid from rice bran. - AMB Express, 8(1): 16. 
